\title{
Corrosion Behavior of Mild Steel and SS 304L in Presence of Dissolved Copper
}

\author{
M. Mobin* and Hina Shabnam \\ Department of Applied Chemistry, Faculty of Engineering and Technology \\ Aligarh Muslim University, Aligarh-202002 (India), \\ *Corresponding author:drmobin@hotmail.com
}

\begin{abstract}
The failure of steel components in multistage flash (MSF) desalination or power plants as a result of the deposition of carryover heavy metals/oxides is a common problem and reported by many authors. The present investigation was undertaken to study the corrosion behavior of mild steel and AISI 304L SS in presence of dissolved Cu ions under different experimental conditions. The experimental conditions include: variation in aqueous medium, $\mathrm{Cu}$ ion concentration, $\mathrm{pH}$ and flow condition. The corrosion rate of mild steel and SS 304L in presence of different concentration of $\mathrm{Cu}$ was determined by weight loss measurements and solvent analysis of iron ions into the test solution after completion of immersion. The amount of $\mathrm{Cu}$ ions present in the test solution after completion of immersion was also estimated using Atomic absorption spectrophotometer. The $\mathrm{pH}$ of the test solution was monitored during the entire period of immersion. Electrochemical techniques like free corrosion potential measurements and potentiodynamic polarization measurements were carried to find out the role of $\mathrm{Cu}$ ions on the corrosion behavior of mild steel and SS 304L. The effect of Cu on corrosion rate of mild steel is quite pronounced and follows interesting trend. However, SS 304L is not affected either in distilled water or artificial seawater and do not show any significant variation in corrosion rates in presence of Cu ions.
\end{abstract}

Keywords: Mild steel; SS 304L; corrosion; copper ions; immersion tests; electrochemical tests

\section{INTRODUCTION}

The corrosion is a major cause of component or material failure in desalination and power plants. Though one or more forms of corrosion are involved during corrosion failure in desalination plants general and pitting corrosion are more common modes of failures. The failure of steel components in desalination or power plants as a result of the deposition of carryover heavy metals/oxides is a common problem and reported by many authors. The problem may appear in the form of pitting or crevices which act as initiators of stress corrosion in the form of stress 
corrosion cracking, corrosion fatigue or intergranular corrosion and result in the failure of components. However, this aspect has been given little attention and is least understood yet has great relevance to seawater desalination and power plants [1]. In seawater processing systems, if dissolved oxygen and $\mathrm{pH}$ are under control, general corrosion is the predominant mode of attack on conventional construction materials such as carbon steel. This form of corrosion is easily controllable and is desirable in the sense that it permits predictive estimates of service life. Pitting, the most detrimental form of attack, is often responsible for the corrosion failures of components in desalination and power plants. In process plants, it accounts at least $90 \%$ of metal damage by corrosion [2]. Out of the several causes of pitting one of the causes attributed to pitting is the contact of steel with heavy metal ions such as $\mathrm{Cu}$ [3]. This aspect has been given little attention and is least understood yet has great relevance to seawater desalination and power plants [4]. A survey of literature shows that a number of cases regarding the $\mathrm{Cu}$ induced pitting corrosion of iron and galvanized pipes and tanks in recirculating hot water system have been reported [5-8]. A very small concentration of $\mathrm{Cu}$ was found to be sufficient to cause accelerated attack.

In multistage flash (MSF) desalination plants the recirculating brine generally contains $\mathrm{Cu}$. The source of $\mathrm{Cu}$ is the cupronickel condenser tubes in the distiller which are subjected to vapor phase corrosion leading to the contamination of brine and condensate with $\mathrm{Cu}$ and $\mathrm{Ni}$. The deterioration of protective $\mathrm{Cu}$ oxide during the start up following outage also contributes $\mathrm{Cu}$ in the brine and distillate. The $\mathrm{Cu}$ in the brine/distillate gets deposited on the flash chamber components and initiate accelerated corrosion attack [9-10]. In power-water cogeneration plants the condensate from the MSF plant is sent to the boiler and carry over $\mathrm{Cu}$ is likely to get deposited over the water touched parts. In steam turbines, the deposits along the steam path resulting from the boiler carryover are most problematic. The deposits are detrimental to efficiency of the turbine. A study of the corrosion related problems in steam generating equipments shows that while $26 \%$ of the failures are attributed to pitting; $57 \%$ are caused by deposition on blades formed from high dissolved and suspended solid carryover of steam [11].

The present work is concerned with the effect of $\mathrm{Cu}$ on localized corrosion behavior of mild steel and SS 304L under different experimental conditions. The experimental conditions which have been taken into account are the nature of aqueous medium, $\mathrm{Cu}$ ion concentration, $\mathrm{pH}$, temperature and flow condition. The studies include: immersion tests, spectrophotometric estimation of iron ions, $\mathrm{pH}$ monitoring, analysis of free $\mathrm{Cu}$ ions by atomic absorption spectrophotometer and electrochemical techniques like free corrosion potential measurements and potentiodynamic polarization measurements. The results of the study shall provide important information about the role of $\mathrm{Cu}$ carryover on the failure of components in desalination and power plant.

\section{EXPERIMENTAL}

\subsection{Preparation of Specimens}

Commercial grade mild steel and AISI 304L SS were used for the immersion and electrochemical tests. For immersion tests coupons of dimension $(4.0 \times 3.2 \times 0.13) \mathrm{cm}$ were cut 
from the sheet. To hold the specimens, a hole of $1.5 \mathrm{~mm}$ diameter was made near the edge. For electrochemical tests circular samples with $1.5 \mathrm{~cm}$ diameter were cut from the mild steel and SS 304L sheets. A conducting wire was spot welded to one face of the specimens for the electrical connection and the specimens were then mounted in a cold setting resin to provide a crevice free mount. The specimens were then machined and abraded on 180 grit SiC paper to simulate near service conditions. The abraded specimens were washed and degreased with ethyl alcohol and dried up. The composition of steels as analyzed by optical emission spectrophotometer is given in the Table 1.

Table 1. Composition of steel as analyzed by optical emission spectrometer

\begin{tabular}{|c|c|c|c|c|c|c|c|c|c|c|}
\hline \multirow{2}{*}{ Steel } & \multicolumn{10}{|c|}{ \% Composition of elements } \\
\cline { 2 - 11 } & $\mathrm{C}$ & $\mathrm{Si}$ & $\mathrm{Mn}$ & $\mathrm{P}$ & $\mathrm{S}$ & $\mathrm{Cr}$ & $\mathrm{Ni}$ & $\mathrm{Mo}$ & $\mathrm{Cu}$ & $\mathrm{Fe}$ \\
\hline $\begin{array}{l}\text { Mild } \\
\text { Steel }\end{array}$ & 0.206 & 0.004 & 0.166 & 0.028 & 0.044 & 0.078 & 0.088 & 0.114 & 0.052 & $\mathrm{Bal}$ \\
\hline $\begin{array}{l}\text { AISI } \\
\text { 304L }\end{array}$ & 0.048 & 0.440 & 1.587 & 0.028 & 0.007 & 18.002 & 7.635 & 0.353 & 0.326 & $\mathrm{Bal}$ \\
\hline
\end{tabular}

\subsubsection{Preparation of test solution}

The test solutions were made up with distilled water and artificial seawater. The composition of artificial seawater is given in Table 2 [12]. The solutions containing 1, 10, 20, 30, 40 and 100 ppm of $\mathrm{Cu}$ were prepared in distilled water and artificial seawater using analar grade $\mathrm{CDH}$ chemicals. The $\mathrm{pH}$ of the solutions was adjusted using $\mathrm{NH}_{4} \mathrm{OH}$ and $\mathrm{CH}_{3} \mathrm{COOH}$. For test solution made up with distilled water a $\mathrm{pH}$ of 5.0, 6.5 and 8.5 was maintained whereas for the test solution made up with artificial seawater a $\mathrm{pH}$ of 8.2 was maintained.

Table 2. Chemical composition of artificial seawater [12]

\begin{tabular}{|c|c|}
\hline Compound & Concentration (g/l) \\
\hline $\mathrm{NaCl}$ & 24.53 \\
\hline $\mathrm{MgCl}_{2}$ & 5.20 \\
\hline $\mathrm{Na}_{2} \mathrm{SO}_{4}$ & 4.09 \\
\hline $\mathrm{CaCl}_{2}$ & 1.16 \\
\hline $\mathrm{KCl}$ & 0.695 \\
\hline $\mathrm{NaHCO}_{3}$ & 0.201 \\
\hline $\mathrm{KBr}_{3}$ & 0.101 \\
\hline $\mathrm{H}_{3} \mathrm{BO}_{3}$ & 0.027 \\
\hline $\mathrm{SrCl}_{2}$ & 0.025 \\
\hline $\mathrm{NaF}$ & 0.003 \\
\hline
\end{tabular}




\subsubsection{Immersion test procedures}

Immersion tests were performed in accordance with ASTM designation G31-72 (Re-approved 1990). After taking the initial weight and dimensions, the coupons were hanged in the test solution containing varying concentration of copper ions, with the help of a nylon thread. To avoid the galvanic and crevice corrosion the coupons were loosely tied with the nylon thread. A blank experiment was also carried out for the comparison purpose. The immersion tests were carried out under both static and dynamic condition. Under static condition, the tests runs were of 24, 360 and $720 \mathrm{hrs}$ duration for mild steel and 720 and $4320 \mathrm{hrs}$ durations for SS 304L. Under dynamic conditions the runs were of 24 hrs duration. After completion of the immersion test, the specimens were taken out and cleaned following ASTM designation G1-90 and observed for any localized attack. The average corrosion rate was determined using the following relationship:

$$
\text { Corrosion rate }(m p y)=\frac{534 W}{\rho A T}
$$

Where, $\mathrm{W}=$ mass loss in $\mathrm{mg} ; \mathrm{A}=$ area in inch ${ }^{2} ; \mathrm{T}=$ time of exposure in hrs and $\rho=$ density in $\mathrm{g} / \mathrm{cm}^{3}$

\subsection{Solution Analysis of Metal Ion}

Corrosion rate of mild steel and SS 304L was also measured from the determination of total iron ions $\left(\mathrm{Fe}^{2+} / \mathrm{Fe}^{3+}\right)$ entered into the test solution during the course of corrosion. The analysis was performed spectrophotometrically using single beam spectrophotometer. The corrosion rate was calculated using the following relationship:

$$
\text { Corrosion rate }=\frac{m}{s \times t}\left[\mathrm{gm}^{-2} \mathrm{~h}^{-1}\right]
$$

Where, ' $\mathrm{m}$ ' is the mass of corroded metal (calculated from the total iron content determined in the test solution); ' $\mathrm{s}$ ' is the area of the test metal in $\mathrm{m}^{2}$; and ' $\mathrm{t}$ ' is the exposure time in hrs.

\subsection{Monitoring of $\mathbf{p H}$}

The $\mathrm{pH}$ of the different test solutions containing mild steel and SS 304L samples was measured on daily basis. The $\mathrm{pH}$ measurement was continued till the entire period of immersion.

\subsection{Estimation of $\mathrm{Cu}$ Ions in the Test Solution}

To observe the behavior of $\mathrm{Cu}$ on the corrosion of mild steel and SS $304 \mathrm{~L}$, the amount of copper present into the test solutions after the completion of immersion was estimated by using atomic absorption spectrophotometer. 


\subsection{Electrochemical Tests}

To investigate the effect of $\mathrm{Cu}$ on the corrosion behavior of mild steel and SS 304L electrochemical tests like free corrosion potential measurements and potentiodynamic polarization measurements were carried out. The tests were carried out in both distilled water and artificial seawater at room temperature.

\subsubsection{Free corrosion potential measurements}

The free corrosion potential measurements $\left(E_{\text {corr }}\right)$ were carried out in presence and absence of $\mathrm{Cu}$ ions at room temperature under static condition. The change in voltage against SCE used as reference electrode was plotted vs. time. The steel specimen was connected to a wire having alligator clip on both the ends. One end of the alligator clip was attached to the steel specimen and placed into the test solution and other end was connected to multimeter.

\subsubsection{Potentiodynamic polarization measurements}

The potentiodynamic polarization measurements were conducted on EG\&G potentiostat/galvanostat Model 263A. The experiments were carried out using a corrosion cell from $\mathrm{EG} \& \mathrm{G}$; model $\mathrm{K} 0047$, with $\mathrm{Ag} / \mathrm{AgCl}$ electrodes (saturated $\mathrm{KCl}$ ) as reference and $\mathrm{Pt}$ wire as counter electrode. The potentiodynamic polarization measurements were carried out using a scan rate of $0.166 \mathrm{mV}$ commencing at a potential above $250 \mathrm{mV}$ more active than stable open circuit potential. To observe the effect of $\mathrm{Cu}$ in a given aqueous medium potentiodynamic curves were obtained using the same specimen under similar experimental condition except a periodic change in copper ion concentration. However, before starting the scanning at each concentration, the specimen was stabilized for about $1 \mathrm{hr}$ for attaining a steady state which was shown by a stable potential.

\section{RESULTS}

\subsection{Immersion Tests}

The corrosion rates of mild steel and SS 304L in both distilled water and artificial seawater at different experimental conditions as obtained by weight loss measurement technique are shown in Table 3 and 4. In distilled water, under static condition, there is no appreciable influence of $\mathrm{Cu}$ on the corrosion rate of mild steel except at $100 \mathrm{ppm}$ of $\mathrm{Cu}$ concentration where a decrease in corrosion rate is observed. However, the decrease in corrosion rate in presence of $100 \mathrm{ppm} \mathrm{Cu}$ appears to be more appreciable at $\mathrm{pH} 6.5$ and 8.5. Under dynamic condition, in absence of $\mathrm{Cu}$, the corrosion rate of the mild steel increases substantially. However, the presence of $\mathrm{Cu}$ ions causes a lowering in corrosion rate; the lowering in corrosion rate being more pronounced at 100 ppm $\mathrm{Cu}$. In artificial seawater, the corrosion rate of mild steel increases slightly under both static and dynamic conditions. Under experimental conditions, SS 304L is unaffected in both distilled and artificial seawater. In general, there is negligible effect of copper on the corrosion rate of SS 
304L at a pH range between 5-8.2 for an immersion period of $720 \mathrm{hrs}$ and $4320 \mathrm{hrs}$ in both distilled and artificial seawater.

\subsection{Solution Analysis of Metal Ion}

The corrosion rate of mild steel and SS 304L in distilled water and artificial seawater was also measured by determining the total iron ions entered into the test solution during the course of immersion and the result is shown in Table 3 and 4. The corrosion rates as obtained by solvent analysis are consistent with corrosion rates determined by weight loss measurements. The iron analysis in the test solutions was also performed for SS 304L immersed in distilled water and artificial seawater. The results did not show any iron content in the test solution after completion of immersion.

\subsection{Monitoring of $\mathrm{pH}$}

The $\mathrm{pH}$ of the test solutions during the entire period of immersion was measured. Figure 1; show some representative plots of $\mathrm{pH}$ vs. exposure period. In case of mild steel immersed in distilled water containing varying concentration of $\mathrm{Cu}$, except for the solution of $\mathrm{pH} 5.0$ where a slight increase in $\mathrm{pH}$ during initial period of immersion was observed, there is no significant change in $\mathrm{pH}$ in the test solution maintained at $\mathrm{pH} 6.5$ and 8.5. In case of SS 304L immersed in distilled water there was no appreciable change in $\mathrm{pH}$ in the solutions maintained at $\mathrm{pH}$ 5.0, 6.5 and 8.5. In artificial seawater the $\mathrm{pH}$ of the test solution remained almost constant during the entire period of immersion.

\subsection{Estimation of $\mathrm{Cu}$ in the test solution}

The concentration of $\mathrm{Cu}$ present into the test solutions estimated after the completion of immersion is shown in Table 3 and 4. In case of mild steel immersed in distilled and artificial seawater the following behaviors are distinctly observed:

(I) In the solutions containing lower concentration of $\mathrm{Cu}$ (up to $10 \mathrm{ppm}$ ) no $\mathrm{Cu}$ was detected at the end of immersion.

(II) With $\mathrm{Cu}$ concentration exceeding $10 \mathrm{ppm}$ appreciable amount of $\mathrm{Cu}$ remained into the solutions at the end of immersion. The amount of $\mathrm{Cu}$ increased with increasing $\mathrm{pH}$ and decreased with increasing exposure period. In case of 304L

(III) immersed in distilled and artificial seawater nearly all the $\mathrm{Cu}$ ions added into the test solution remained unchanged and estimated by atomic absorption spectrophotometer 

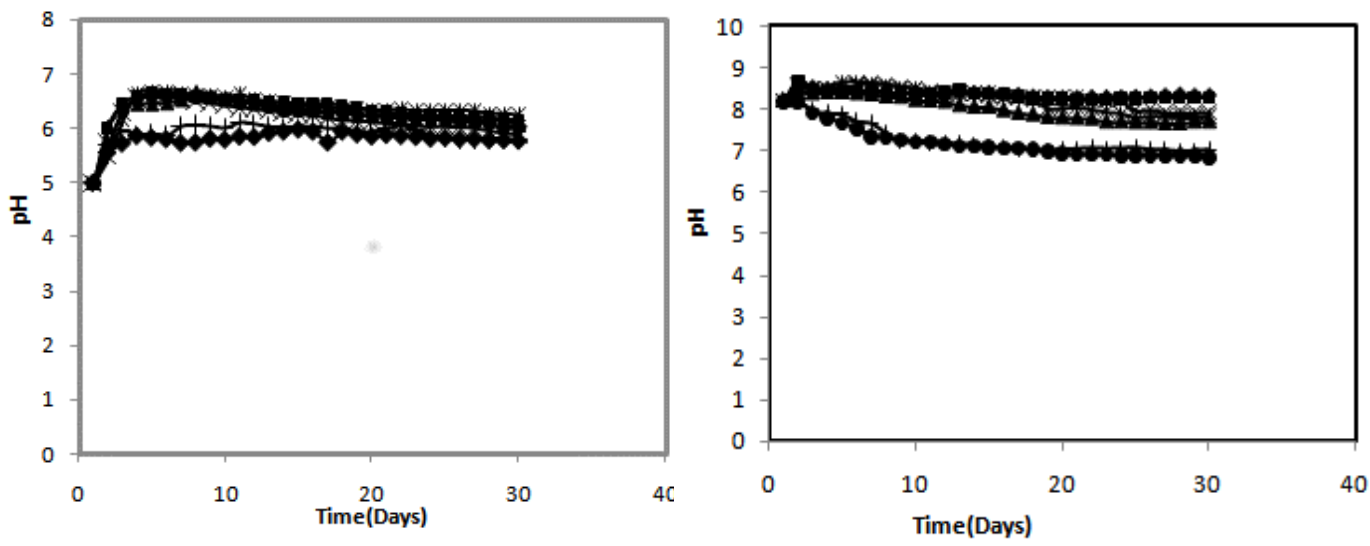

(a)

(b)
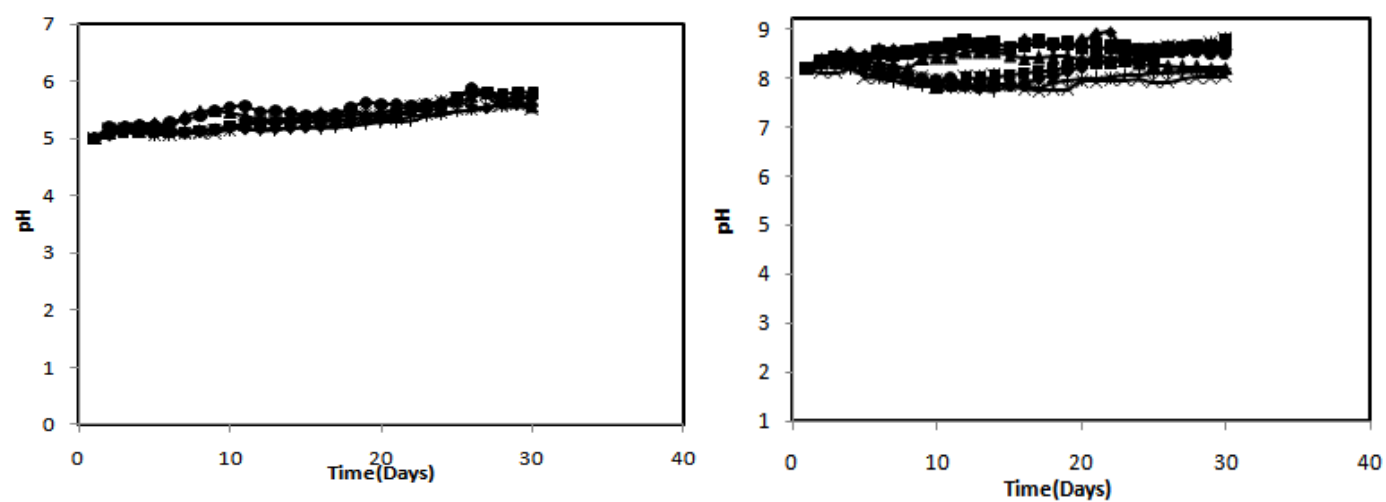

(c)

(d)

Fig.1: $\mathrm{pH}$ vs time plot in absence and presence of varying concentration of $\mathrm{Cu}(\diamond 0 \mathrm{ppm} \mathrm{Cu}$; 1 ppm Cu; $\boldsymbol{\Delta} 10 \mathrm{ppm} \mathrm{Cu} ; \times 20 \mathrm{ppm} \mathrm{Cu}$; $* 30 \mathrm{ppm} \mathrm{Cu}$; $40 \mathrm{ppm} \mathrm{Cu} ;+100 \mathrm{ppm} \mathrm{Cu}$ ) for (a) mild steel in distilled water, pH 5.0 (b) mild steel in artificial seawater, $\mathrm{pH} 8.2$ (c) SS 304L in distilled water, $\mathrm{pH} 5.0$ (d) SS 304L in artificial seawater, $\mathrm{pH} 8.2$. 
Table 3. Effect of $\mathrm{Cu}$ on the corrosion rate of mild steel under different experimental conditions at room temperature

\begin{tabular}{|c|c|c|c|c|c|c|c|c|c|c|c|c|}
\hline \multirow[t]{2}{*}{$\begin{array}{l}\text { Aqueous } \\
\text { medium }\end{array}$} & \multirow[t]{2}{*}{ pH } & \multirow[t]{2}{*}{$\begin{array}{l}\text { Flow } \\
\text { condition }\end{array}$} & \multirow[t]{2}{*}{$\begin{array}{l}\text { Cu ions } \\
\text { conc. } \\
\text { (ppm) }\end{array}$} & \multicolumn{3}{|c|}{$\begin{array}{l}\text { Corrosion rate as obtained } \\
\text { by weight loss } \\
\text { measurements (mpy) }\end{array}$} & \multicolumn{3}{|c|}{$\begin{array}{l}\text { Corrosion rate as } \\
\text { determined by solvent } \\
\text { analysis of iron ions ( } \mathrm{mpy} \text { ) }\end{array}$} & \multicolumn{3}{|c|}{$\begin{array}{l}\text { Conc. Of } \mathrm{Cu} \text { ions left over } \\
\text { in the test solutions (ppm) }\end{array}$} \\
\hline & & & & $24 \mathrm{hrs}$ & $360 \mathrm{hrs}$ & $720 \mathrm{hrs}$ & $24 \mathrm{hrs}$ & $360 \mathrm{hrs}$ & $720 \mathrm{hrs}$ & $24 \mathrm{hrs}$ & $360 \mathrm{hrs}$ & $720 \mathrm{hrs}$ \\
\hline \multirow{30}{*}{$\begin{array}{l}\text { Distilled } \\
\text { water }\end{array}$} & 5.0 & Static & 0 & 4.53 & 4.36 & 4.28 & 4.45 & 4.25 & 4.20 & - & - & - \\
\hline & & ” & 1 & 4.69 & 4.63 & 4.59 & 4.60 & 4.55 & 4.49 & 0.0 & 0.0 & 0.0 \\
\hline & & 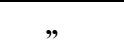 & 10 & 4.71 & 4.69 & 4.60 & 4.69 & 4.60 & 4.55 & 0.0 & 0.0 & 0.0 \\
\hline & & " & 20 & 4.52 & 4.49 & 4.42 & 4.46 & 4.37 & 4.40 & 2.0 & 0.1 & 0.0 \\
\hline & & " & 30 & 4.46 & 4.36 & 4.27 & 4.39 & 4.18 & 4.10 & 7.0 & 0.9 & 0.0 \\
\hline & & ” & 40 & 4.73 & 4.56 & 4.49 & 4.68 & 4.52 & 4.45 & 18.0 & 1.5 & 0.0 \\
\hline & & ” & 100 & 4.11 & 4.04 & 3.94 & 4.06 & 3.80 & 3.70 & 13.0 & 2.4 & 0.4 \\
\hline & & Dynamic & 0 & 51.7 & - & - & 50.1 & - & - & - & - & - \\
\hline & & " & 1 & 23.4 & - & - & 22.3 & - & - & - & - & - \\
\hline & & " & 100 & 18.1 & - & - & 18.0 & - & - & - & - & - \\
\hline & 6.5 & Static & 0 & 3.19 & 3.07 & 2.84 & 3.07 & 2.89 & 2.63 & - & - & - \\
\hline & & " & 1 & 3.28 & 3.19 & 2.91 & 3.19 & 2.97 & 2.71 & 0.0 & 0.0 & 0.0 \\
\hline & & ” & 10 & 3.53 & 3.28 & 3.02 & 3.22 & 3.06 & 2.96 & 0.0 & 0.0 & 0.0 \\
\hline & & " & 20 & 2.83 & 2.65 & 2.47 & 2.83 & 2.79 & 2.40 & 6.0 & 0.4 & 0.0 \\
\hline & & ” & 30 & 2.47 & 2.35 & 2.28 & 2.36 & 2.23 & 2.17 & 10.0 & 1.2 & 0.0 \\
\hline & & ” & 40 & 2.96 & 2.54 & 2.49 & 2.71 & 2.36 & 2.40 & 20.0 & 2.0 & 0.0 \\
\hline & & " & 100 & 1.68 & 1.12 & 0.98 & 1.67 & 1.15 & 0.73 & 30.0 & 4.9 & 0.1 \\
\hline & & Dynamic & 0 & 11.4 & - & - & 10.31 & - & - & - & - & - \\
\hline & & " & 1 & 10.1 & - & - & 9.89 & - & - & - & - & - \\
\hline & & , & 100 & 6.07 & - & - & 5.93 & - & - & - & - & - \\
\hline & 8.5 & Static & 0 & 3.04 & 2.76 & 2.60 & 2.98 & 2.79 & 2.58 & - & - & - \\
\hline & & " & 1 & 3.26 & 2.95 & 2.69 & 3.16 & 2.83 & 2.65 & 0.0 & 0.0 & 0.0 \\
\hline & & 川 & 10 & 3.58 & 3.27 & 2.72 & 3.55 & 3.06 & 2.80 & 0.0 & 0.0 & 0.0 \\
\hline & & " & 20 & 2.93 & 2.65 & 2.67 & 2.90 & 2.82 & 2.76 & 5.0 & 0.0 & 0.0 \\
\hline & & " & 30 & 2.85 & 2.74 & 2.49 & 2.77 & 2.65 & 2.38 & 19.0 & 1.8 & 0.0 \\
\hline & & ” & 40 & 2.76 & 2.62 & 2.58 & 2.82 & 2.60 & 2.49 & 30.0 & 2.3 & 0.0 \\
\hline & & ” & 100 & 1.81 & 1.05 & 0.86 & 1.81 & 1.30 & 0.66 & 50.0 & 7.0 & 0.2 \\
\hline & & Dynamic & 0 & 13.54 & - & - & 12.96 & - & - & - & - & - \\
\hline & & ” & 1 & 15.02 & - & - & 16.72 & - & - & - & - & - \\
\hline & & ” & 100 & 12.42 & - & - & 11.70 & - & - & - & - & - \\
\hline \multirow{10}{*}{$\begin{array}{l}\text { Artificial } \\
\text { seawater }\end{array}$} & 8.2 & Static & 0 & 3.17 & 2.97 & 2.48 & 3.09 & 3.01 & 2.64 & - & - & - \\
\hline & & " & 1 & 3.56 & 3.22 & 2.96 & 3.49 & 3.32 & 2.90 & 0.0 & 0.0 & 0.0 \\
\hline & & " & 10 & 3.73 & 3.54 & 3,29 & 3.56 & 3.65 & 3.06 & 2.1 & 0.9 & 0.0 \\
\hline & & " & 20 & 3.86 & 3.63 & 3.42 & 3.84 & 3.80 & 3.27 & 8.9 & 1.5 & 0.2 \\
\hline & & ” & 30 & 3.99 & 3.90 & 3.67 & 3.90 & 3.76 & 3.53 & 12.7 & 5.3 & 0.9 \\
\hline & & ״ & 40 & 4.05 & 3.88 & 3.73 & 3.99 & 3.80 & 3.65 & 29.1 & 10.4 & 5.3 \\
\hline & & ” & 100 & 3.99 & 3.76 & 3.48 & 3.86 & 3.70 & 3.49 & 63.5 & 14.7 & 3.2 \\
\hline & & Dynamic & 0 & 23.57 & - & - & 22.49 & - & - & - & - & - \\
\hline & & " & 1 & 28.42 & - & - & 26.48 & - & - & - & - & - \\
\hline & & " & 100 & 33.01 & - & - & 32.06 & - & - & - & - & - \\
\hline
\end{tabular}


Table 4. Effect of $\mathrm{Cu}$ on the corrosion rate of SS 304L under different experimental conditions at room temperature

\begin{tabular}{|c|c|c|c|c|c|c|c|c|c|}
\hline \multirow[t]{2}{*}{$\begin{array}{l}\text { Aqueous } \\
\text { medium }\end{array}$} & \multirow[t]{2}{*}{ pH } & \multirow[t]{2}{*}{$\begin{array}{l}\text { Flow } \\
\text { condition }\end{array}$} & \multirow[t]{2}{*}{$\begin{array}{l}\text { Cu ions } \\
\text { conc. (ppm) }\end{array}$} & \multicolumn{2}{|c|}{$\begin{array}{l}\text { Corrosion rate as } \\
\text { obtained by weight loss } \\
\text { measurements (mpy) }\end{array}$} & \multicolumn{2}{|c|}{$\begin{array}{l}\text { Corrosion rate as } \\
\text { determined by solvent } \\
\text { analysis of iron ions } \\
\text { ( mpy) }\end{array}$} & \multicolumn{2}{|c|}{$\begin{array}{l}\text { Conc. of } \mathrm{Cu} \text { ions left } \\
\text { over in the test } \\
\text { solutions (ppm) }\end{array}$} \\
\hline & & & & $720 \mathrm{hrs}$ & $4320 \mathrm{hrs}$ & $720 \mathrm{hrs}$ & $4320 \mathrm{hrs}$ & $720 \mathrm{hrs}$ & $4320 \mathrm{hrs}$ \\
\hline \multirow[t]{21}{*}{ Distilled water } & 5.0 & Static & $0 \mathrm{ppm}$ & Nil & Nil & Nil & Nil & - & - \\
\hline & & , & $1 \mathrm{ppm}$ & , & , & ” & , & 0.9 & 0.9 \\
\hline & & , & $10 \mathrm{ppm}$ & 川 & 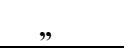 & , & , & 9.0 & 8.2 \\
\hline & & , & $20 \mathrm{ppm}$ & , & , & 川 & , & 18.0 & 18.0 \\
\hline & & ״ & $30 \mathrm{ppm}$ & 川 & 川 & 川 & 川 & 27.0 & 26.3 \\
\hline & & ״ & 40ppm & 川 & 川 & ” & 川 & 36.0 & 38.0 \\
\hline & & " & $100 \mathrm{ppm}$ & " & " & " & " & 57.0 & 38.0 \\
\hline & 6.5 & Static & 0ppm & , & , & , & , & - & - \\
\hline & & ” & $1 \mathrm{ppm}$ & ” & , & , & , & 0.9 & 0.7 \\
\hline & & ״ & $10 \mathrm{ppm}$ & 川 & 川 & " & 川 & 9.2 & 9.1 \\
\hline & & ” & $20 \mathrm{ppm}$ & ” & ” & , & 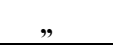 & 18.0 & 17.0 \\
\hline & & 川 & 30ppm & ” & 川 & 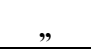 & ” & 28.0 & 26.3 \\
\hline & & " & 40ppm & 川 & 川 & 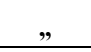 & , & 38.0 & 37.0 \\
\hline & & ״ & $100 \mathrm{ppm}$ & ״ & ״ & ” & ״ & 52.0 & 36.0 \\
\hline & 8.5 & Static & $0 \mathrm{ppm}$ & 川 & ” & 川 & 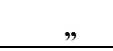 & - & - \\
\hline & & ״ & $1 \mathrm{ppm}$ & ” & ” & ” & ” & 0.7 & 0.7 \\
\hline & & 川 & $10 \mathrm{ppm}$ & " & " & " & " & 8.1 & 7.9 \\
\hline & & ״ & $20 \mathrm{ppm}$ & ״ & " & ״ & " & 19.0 & 18.0 \\
\hline & & , & $30 \mathrm{ppm}$ & ״ & ״ & ״ & ״ & 29.0 & 27.0 \\
\hline & & ״ & 40ppm & ״ & " & 川 & ״ & 38.0 & 37.0 \\
\hline & & , & $100 \mathrm{ppm}$ & " & " & " & " & 55.0 & 47.0 \\
\hline \multirow{7}{*}{$\begin{array}{l}\text { Artificial } \\
\text { seawater }\end{array}$} & 8.2 & Static & 0ppm & " & $"$ & $"$ & " & - & - \\
\hline & & , & $1 \mathrm{ppm}$ & 川 & " & " & " & 0.9 & 0.8 \\
\hline & & 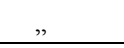 & $10 \mathrm{ppm}$ & " & , & " & " & 8.3 & 8.2 \\
\hline & & 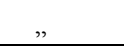 & $20 \mathrm{ppm}$ & " & " & 川 & ״ & 19.0 & 18.0 \\
\hline & & 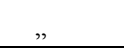 & 30ppm & " & ״ & " & " & 28.0 & 27.0 \\
\hline & &, & 40ppm & " & , & " & " & 37.0 & 36.0 \\
\hline & & $"$ & $100 \mathrm{ppm}$ & " & " & " & " & 49.0 & 39.0 \\
\hline
\end{tabular}

\subsection{Free Corrosion Potential Measurements}

The typical potential vs. time plots for mild steel in distilled water and artificial seawater in absence and presence of 1 and $100 \mathrm{ppm}$ of $\mathrm{Cu}$ are shown in Figure 2(a,b). In distilled water at pH 5 , the initial potential of mild steel is $-766 \mathrm{mv}$; this is followed by a decrease in negative potential till a near steady state was attained at about $-650 \mathrm{mv}$. In presence of $\mathrm{Cu}$ ions a significant 
ennoblement in $E_{\text {corr }}$ is observed; the shift being more pronounced at $100 \mathrm{ppm} \mathrm{Cu}$. In artificial seawater the stable potential of mild steel is around $-800 \mathrm{mv}$. The addition of $\mathrm{Cu}$ ions shifts the $E_{\text {corr }}$ in more noble direction. The ennoblement in $E_{\text {corr }}$ is more pronounced at $100 \mathrm{ppm}$ of $\mathrm{Cu}$. The potential vs. time plots for SS 304L in distilled water and artificial seawater is shown in figure 2(c,d). In general, the presence of $\mathrm{Cu}$ ions shifts the $E_{\text {corr }}$ of $304 \mathrm{~L}$ SS to a more noble direction in both the aqueous medium under investigation.

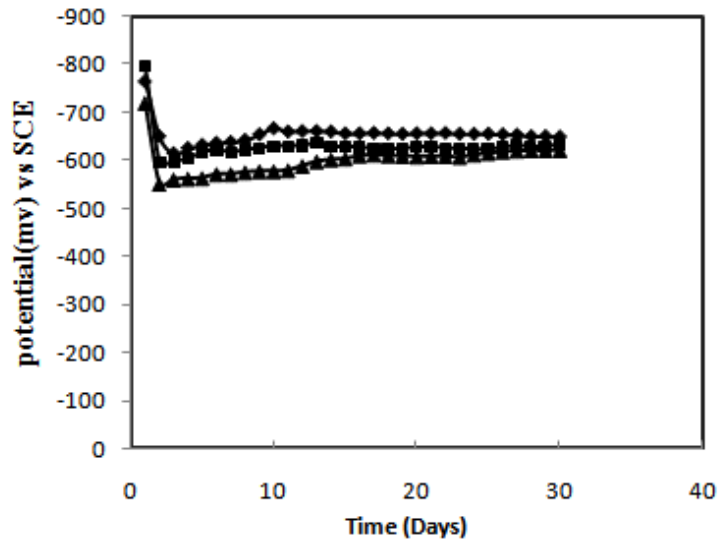

(a)

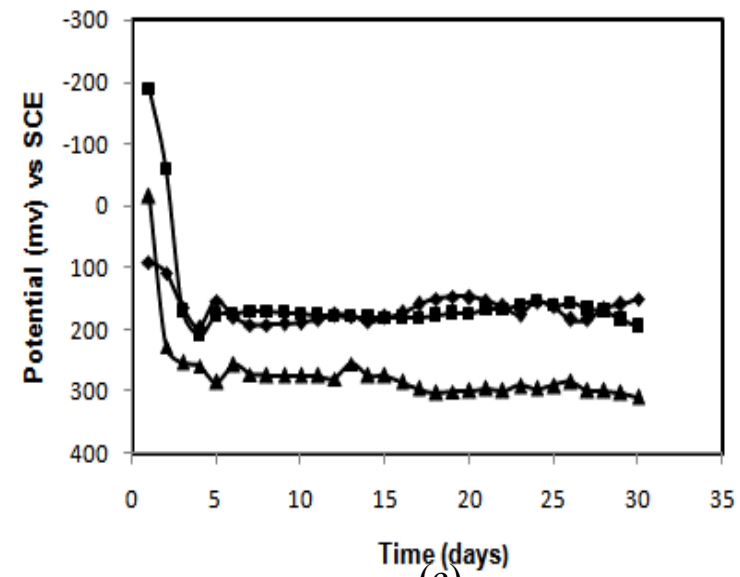

(c)

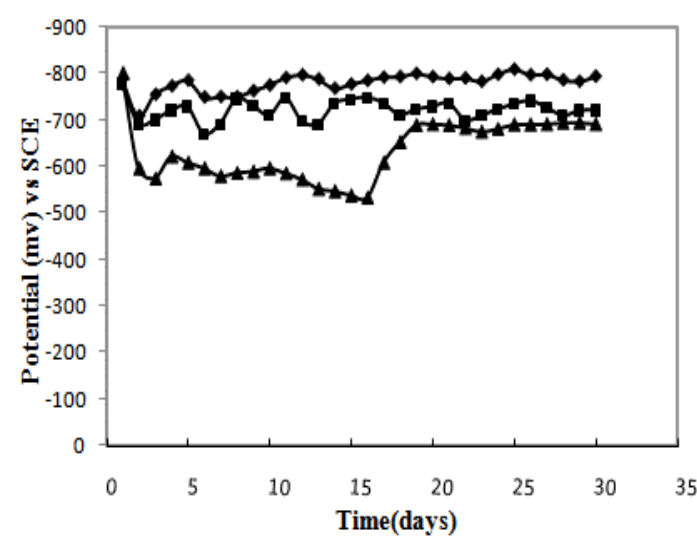

(b)

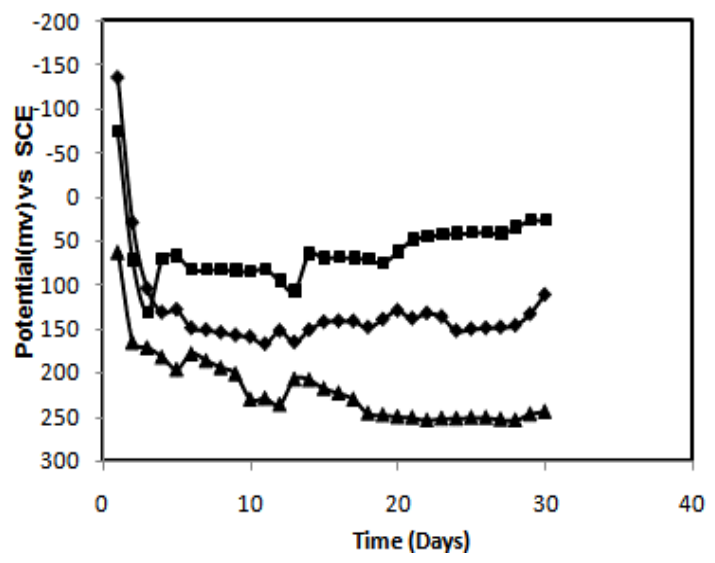

(d)

Fig.2: $E_{\text {corr }}$ vs. time plot in absence and presence of varying concentration of $\mathrm{Cu}(\diamond 0 \mathrm{ppm} \mathrm{Cu}$; - 1ppm Cu; $\boldsymbol{\Delta} 100 \mathrm{ppm} \mathrm{Cu}$ ) (a) mild steel in distilled water, pH 5.0 (b) mild steel in artificial seawater, $\mathrm{pH} 8.2$ (c) SS 304L in distilled water, $\mathrm{pH} 5.0$ (d) SS 304L in artificial seawater, $\mathrm{pH}$ 8.2 .

\subsection{Potentiodynamic Polarization Measurements}

The potentiodynamic polarization curves for mild steel and SS 304L in distilled and artificial seawater in absence and presence of $\mathrm{Cu}$ ions are shown in Figures 3-9. The values of $E_{\text {corr }}, I_{\text {corr }}$, cathodic slope, anodic slope, $\mathrm{Rp}$ and corrosion rate as obtained from these curves are shown in Table 5. For mild steel immersed in distilled water, at both $\mathrm{pH} 5$ and 6.5, an increase in $\mathrm{Cu}$ ion concentration causes a substantial increase in corrosion rate. However, at $\mathrm{pH} 8.5$ a reverse trend 
is obtained. In artificial seawater, the corrosion rate though increases on increasing $\mathrm{Cu}$ ion concentration but the values of $E_{\text {corr }}$ remained constant.

In case of SS 304L the presence of $\mathrm{Cu}$ ions in the aqueous medium causes a significant positive shift in $E_{\text {corr }}$ values. The positive shifting in $E_{\text {corr }}$ is more distinct at $100 \mathrm{ppm}$ of $\mathrm{Cu}$. However, in general, the corrosion rate of SS 304L appears to be unaffected due to the presence of $\mathrm{Cu}$ ions.

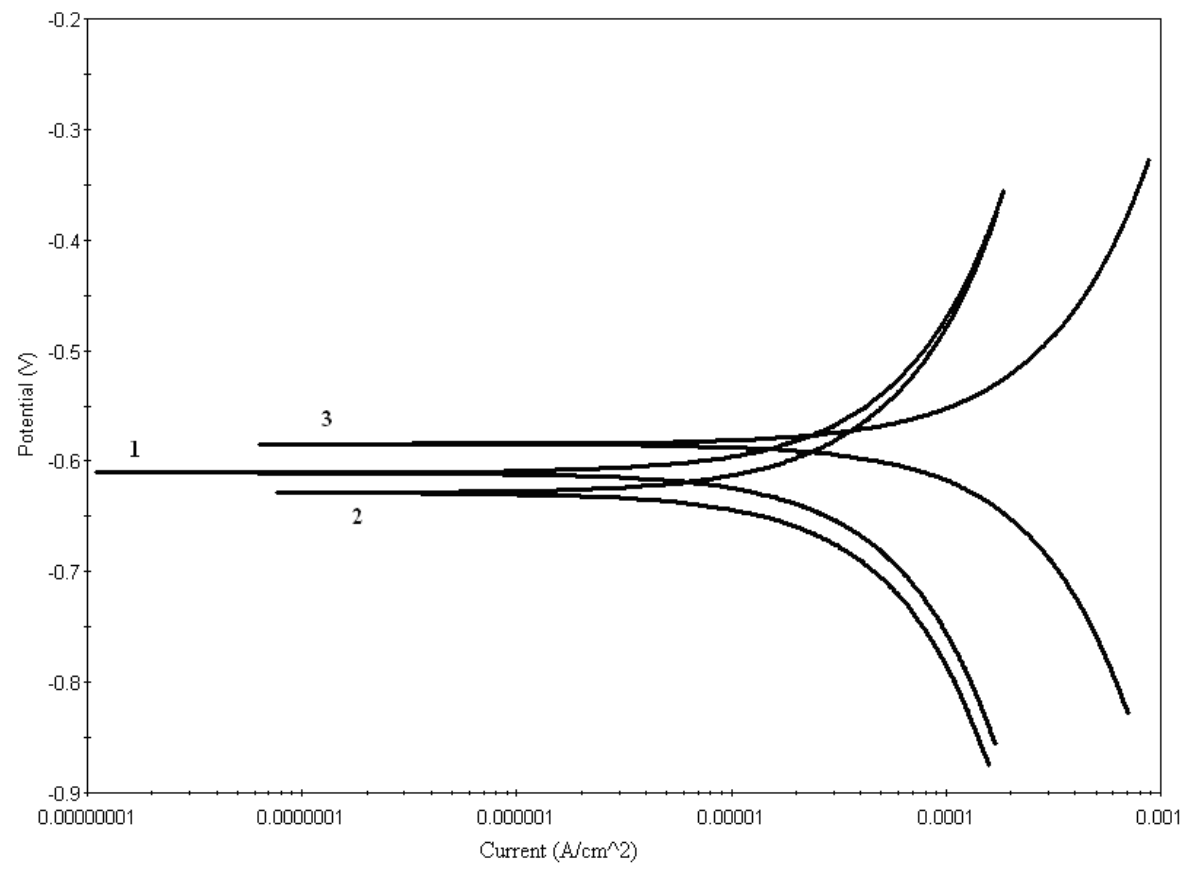

Fig.3: Potentidynamic polarization curves for mild steel in distilled water $(\mathrm{pH}=5.0)$ in absence and presence of varying concentration of $\mathrm{Cu}$ (1)Blank (2)1 ppm (3)100ppm 


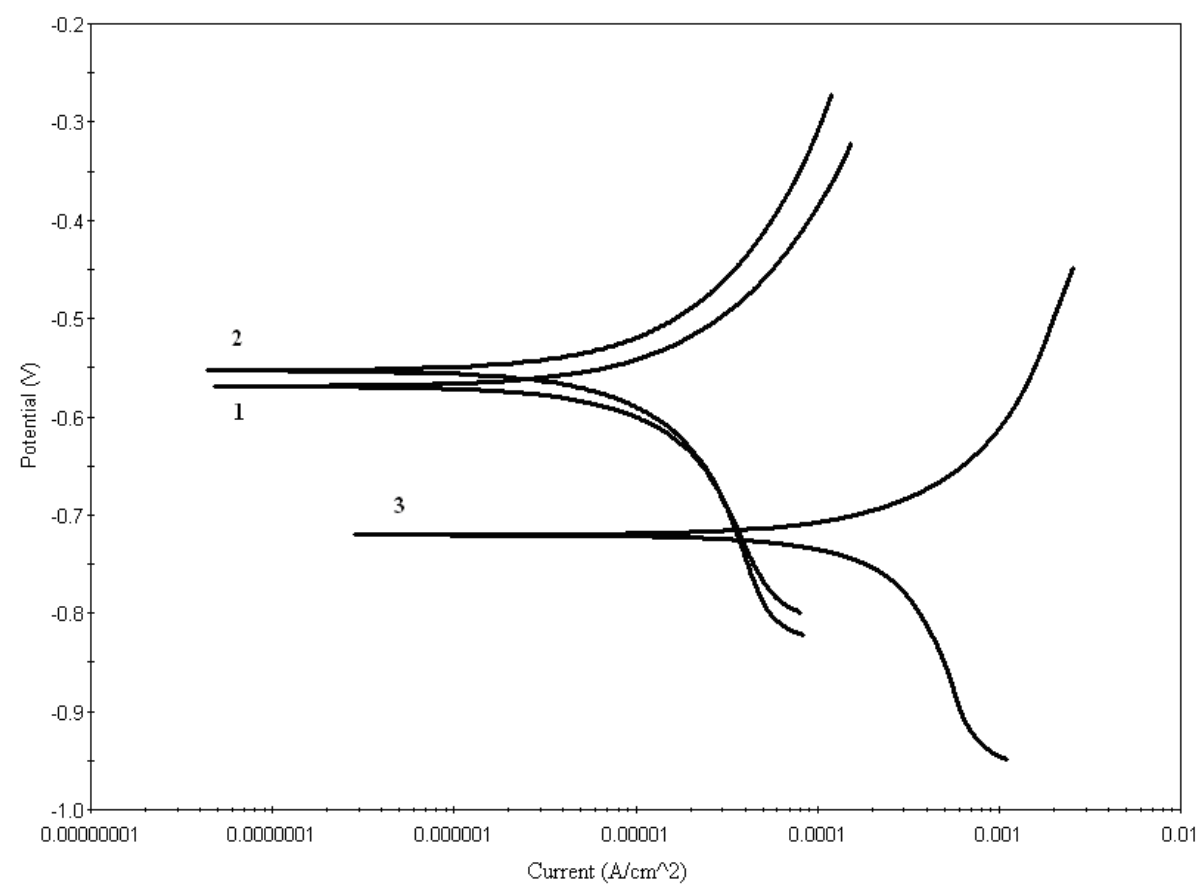

Fig.4: Potentidynamic polarization curves for mild steel in distilled water $(\mathrm{pH}=6.5)$ in absence and presence of varying concentration of $\mathrm{Cu}$ (1) Blank (2)1ppm (3) 100ppm.

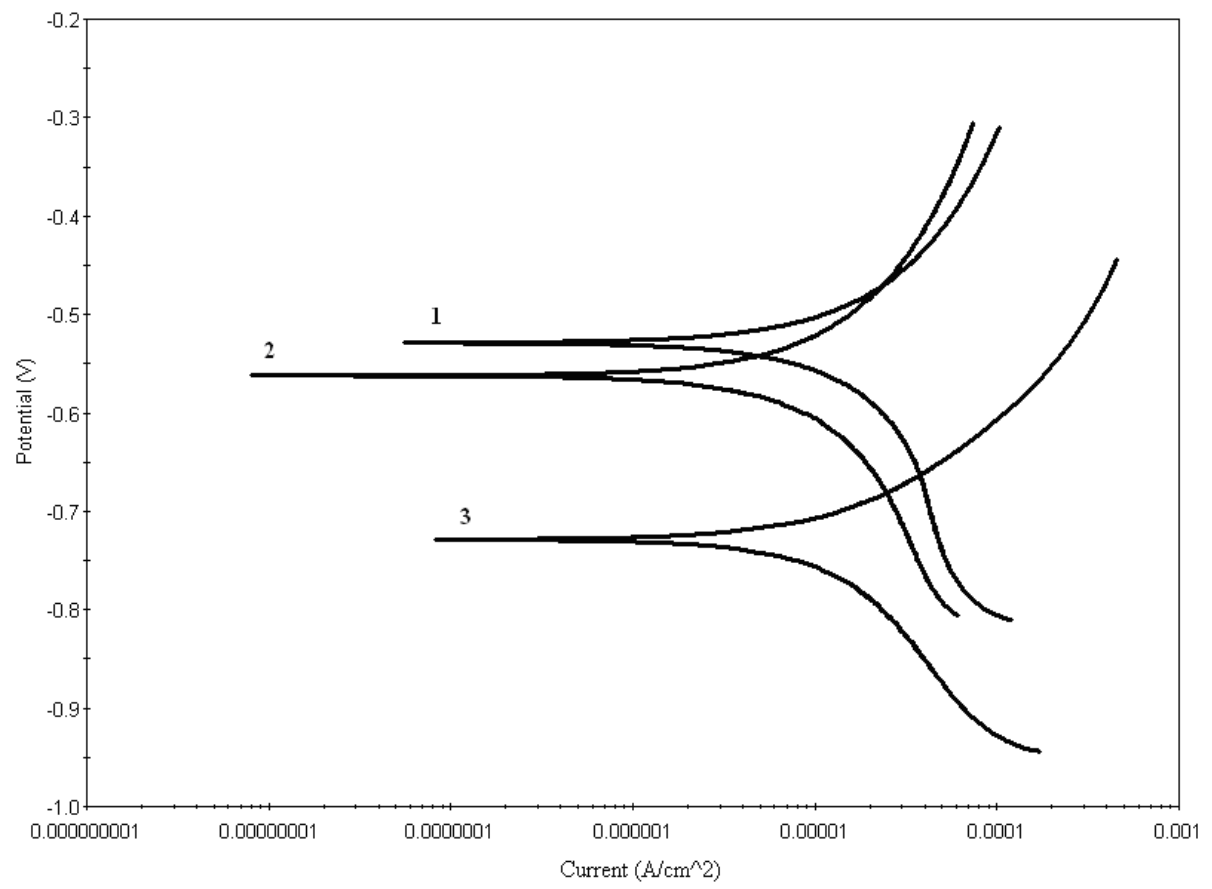

Fig.5: Potentidynamic polarization curves for mild steel in distilled water $(\mathrm{pH}=8.5)$ in absence and presence of varying concentration of $\mathrm{Cu}$ (1) Blank (2)1ppm (3)100ppm. 


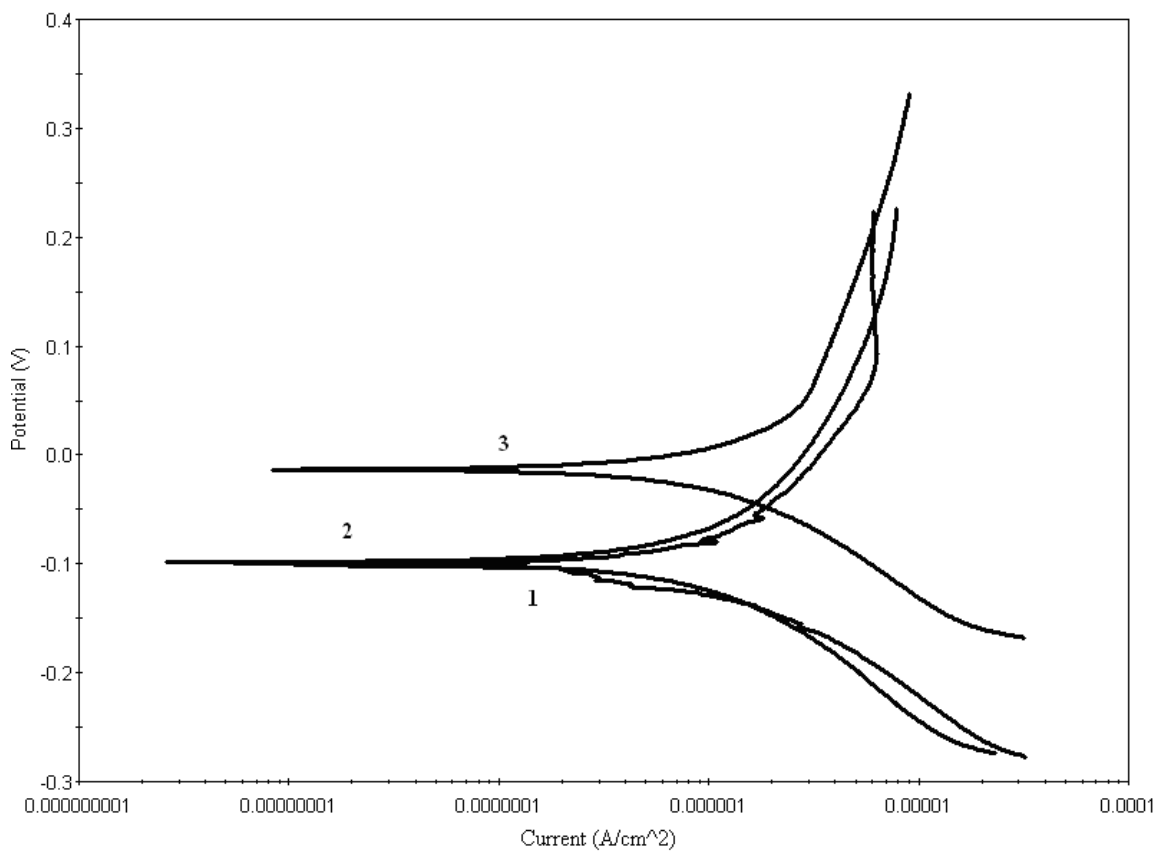

Fig.6: Potentidynamic polarization curves for mild steel in artificial seawater $(\mathrm{pH}=8.2)$ in absence and presence of varying concentration of $\mathrm{Cu}$ (1) Blank (2) 1ppm (3)100ppm.

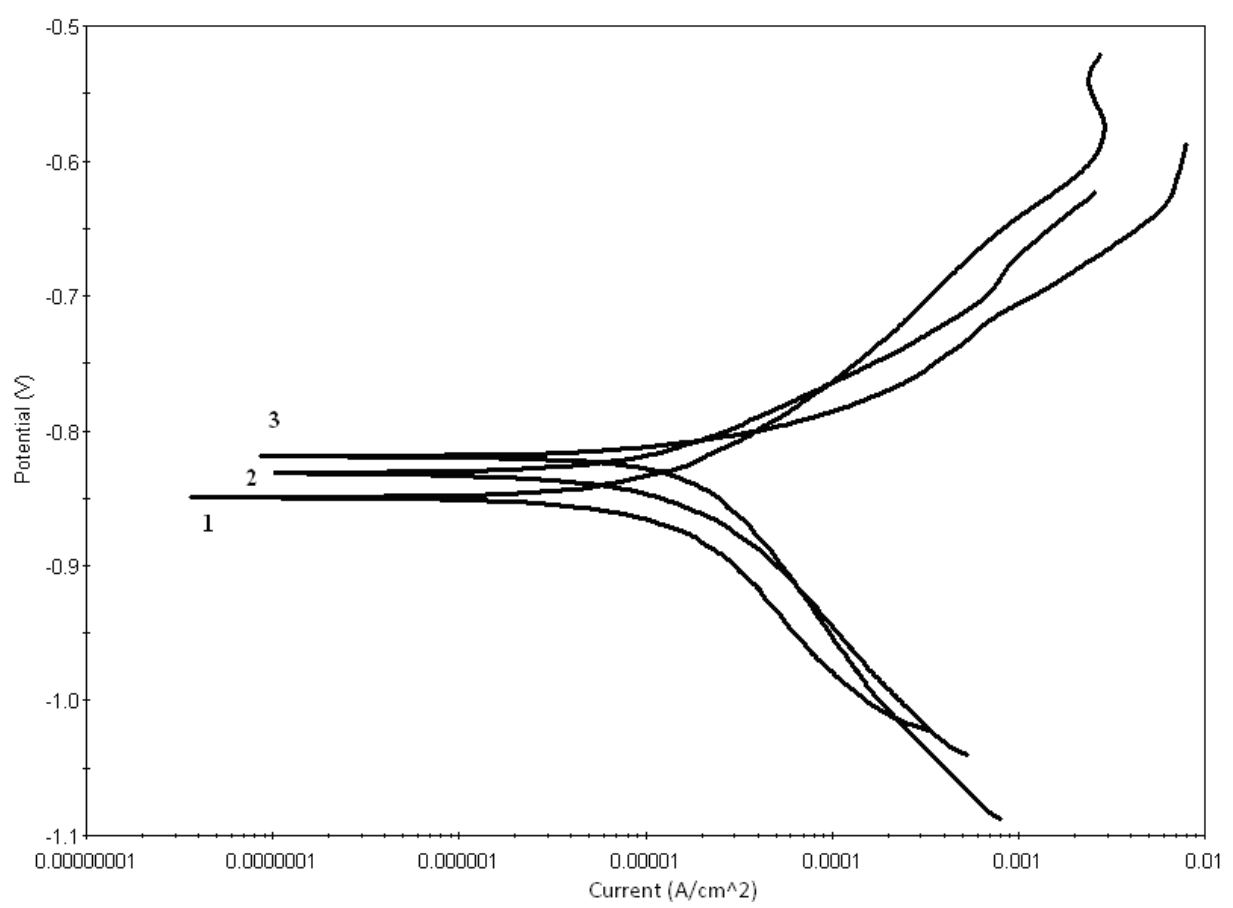

Fig.7: Potentidynamic polarization curves for SS 304L steel in distilled water $(\mathrm{pH}=5.0)$ in absence and presence of varying concentration of $\mathrm{Cu}$ (1)Blank (2)1 ppm (3)100ppm 


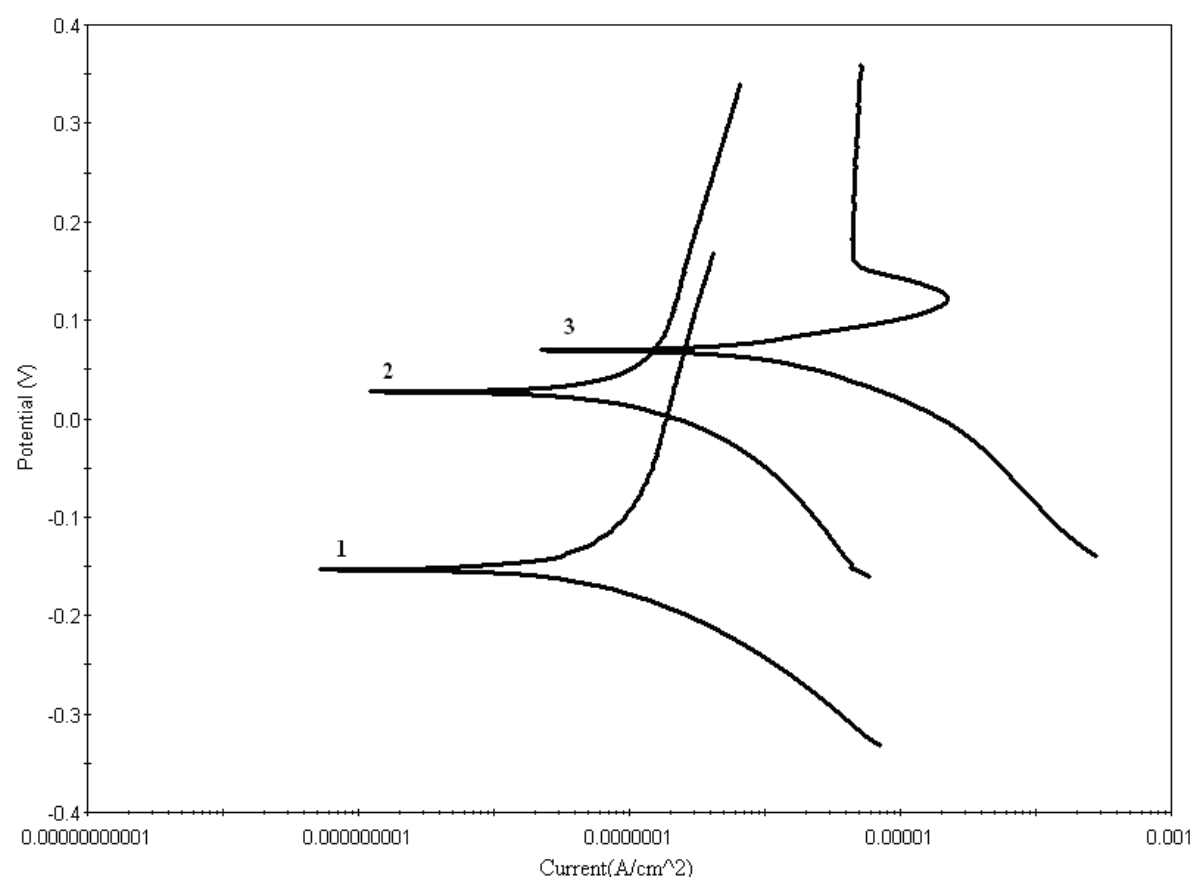

Fig.8: Potentidynamic polarization curves for SS 304Lsteel in distilled water $(\mathrm{pH}=6.5)$ in absence and presence of varying concentration of $\mathrm{Cu}$ (1) Blank (2) 1ppm (3)100ppm.

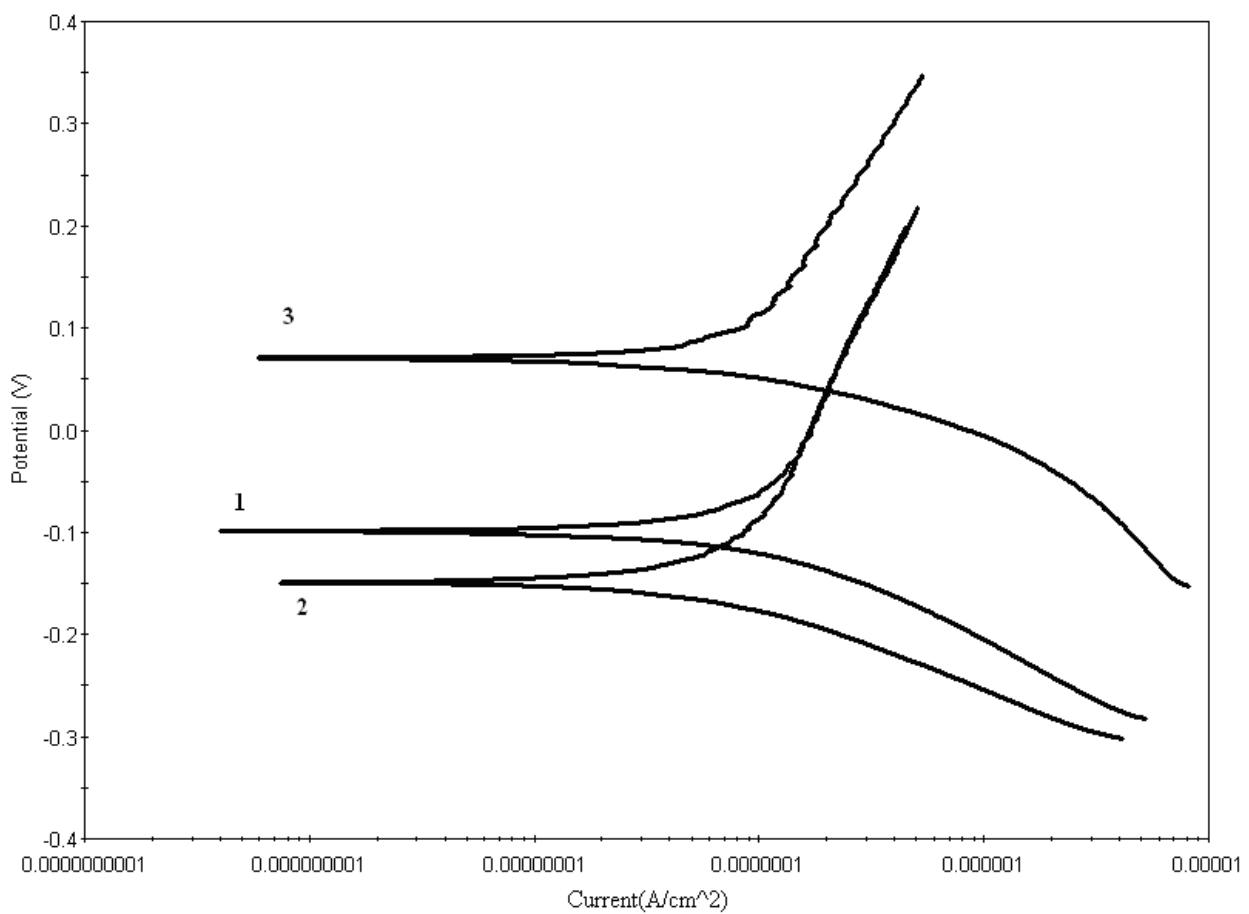

Figure 9: Potentidynamic polarization curves for SS 304L in distilled water $(\mathrm{pH}=8.5)$ in absence and presence of varying concentration of $\mathrm{Cu}$ (1)Blank (2)1ppm (3)100ppm. 
Table 5. Corrosion parameters for mild steel and SS 304L in distilled water and artificial seawater as obtained by potentiodynamic polarization measurements.

\begin{tabular}{|c|c|c|c|c|c|c|c|c|c|}
\hline Alloy & $\begin{array}{l}\text { Aqueous } \\
\text { medium }\end{array}$ & pH & $\begin{array}{c}\text { Cu ions } \\
\text { conc. } \\
\text { (ppm) }\end{array}$ & $\begin{array}{l}\mathbf{E}_{\text {corr }} \\
(\mathrm{mv})\end{array}$ & $I_{\text {corr }}\left(A / \mathbf{c m}^{2}\right)$ & $\beta_{c}(m v)$ & $\beta_{\mathrm{a}}(\mathrm{mv})$ & $\begin{array}{c}\mathbf{R}_{\mathrm{p}}(\mathbf{o h m}- \\
\left.\mathrm{cm}^{2}\right)\end{array}$ & $\begin{array}{l}\text { Corrosion } \\
\text { rate (mpy) }\end{array}$ \\
\hline \multirow[t]{12}{*}{ Mild steel } & $\begin{array}{l}\text { Distilled } \\
\text { water }\end{array}$ & 5.0 & $0 \mathrm{ppm}$ & -610 & $4.7 \times 10^{-4}$ & 3560.56 & 2705.49 & $1.42 \times 10^{3}$ & 107.7 \\
\hline & & & $1 \mathrm{ppm}$ & -628 & $2.4 \times 10^{-4}$ & 1891.23 & 1562.81 & $1.53 \times 10^{3}$ & 55.3 \\
\hline & & & $100 \mathrm{ppm}$ & -584 & $1.1 \times 10^{-3}$ & 2560.83 & 1339.78 & $3.2 \times 10^{2}$ & 269.2 \\
\hline & & 6.5 & 0ppm & -568 & $5.5 \times 10^{-5}$ & 2714.92 & 428.197 & $2.9 \times 10^{3}$ & 12.7 \\
\hline & & & $1 \mathrm{ppm}$ & -552 & $5.1 \times 10^{-5}$ & 1584.76 & 569.46 & $3.5 \times 10^{3}$ & 11.9 \\
\hline & & & $100 \mathrm{ppm}$ & -720 & $9.4 \times 10^{-4}$ & 2032.00 & 433.44 & $1.4 \times 10^{2}$ & 216.0 \\
\hline & & 8.5 & $0 \mathrm{ppm}$ & -528 & $1.0 \times 10^{-4}$ & 10081.6 & 721.17 & $2.9 \times 10^{3}$ & 24.2 \\
\hline & & & $1 \mathrm{ppm}$ & -562 & $8.3 \times 10^{-5}$ & 3932.02 & 1031.30 & $4.2 \times 10^{3}$ & 19.0 \\
\hline & & & $100 \mathrm{ppm}$ & -728 & $2.6 \times 10^{-5}$ & 424.13 & 209.77 & $2.3 \times 10^{3}$ & 5.9 \\
\hline & $\begin{array}{l}\text { Artificial } \\
\text { seawater }\end{array}$ & 8.2 & 0ppm & -849 & $2.8 \times 10^{-5}$ & 241.02 & 149.41 & $1.4 \times 10^{3}$ & 6.5 \\
\hline & & & $1 \mathrm{ppm}$ & -831 & $1.9 \times 10^{-5}$ & 154.50 & 93.23 & $1.3 \times 10^{3}$ & 4.3 \\
\hline & & & 100ppm & -818 & $3.2 \times 10^{-5}$ & 240.18 & 86.56 & $8.6 \times 10^{2}$ & 7.5 \\
\hline \multirow[t]{9}{*}{ SS 304L } & $\begin{array}{l}\text { Distilled } \\
\text { water }\end{array}$ & 5.0 & $0 \mathrm{ppm}$ & -102 & $2.5 \times 10^{-6}$ & 186.40 & 679.15 & $2.5 \times 10^{4}$ & 0.59 \\
\hline & & & $1 \mathrm{ppm}$ & -98 & $2.4 \times 10^{-6}$ & 220.61 & 578.50 & $2.8 \times 10^{4}$ & 0.56 \\
\hline & & & $100 \mathrm{ppm}$ & -13 & $3.6 \times 10^{-6}$ & 211.38 & 876.15 & $2.0 \times 10^{4}$ & 0.83 \\
\hline & & 6.5 & $0 \mathrm{ppm}$ & -151 & $1.0 \times 10^{-7}$ & 95.7 & 561.31 & $3.3 \times 10^{5}$ & 0.024 \\
\hline & & & $1 \mathrm{ppm}$ & +29 & $2.4 \times 10^{-7}$ & 131.39 & 889.06 & $2.0 \times 10^{5}$ & 0.055 \\
\hline & & & $100 \mathrm{ppm}$ & +69 & $7.9 \times 10^{-6}$ & 133.78 & 992.10 & $5.1 \times 10^{4}$ & 1.8 \\
\hline & & 8.5 & $0 \mathrm{ppm}$ & -97 & $1.3 \times 10^{-7}$ & 119.41 & 601.09 & $3.5 \times 10^{5}$ & 0.031 \\
\hline & & & $1 \mathrm{ppm}$ & -149 & $8.7 \times 10^{-8}$ & 96.06 & 502.86 & $4.0 \times 10^{5}$ & 0.020 \\
\hline & & & $100 \mathrm{ppm}$ & +74 & $1.8 \times 10^{-7}$ & 127.35 & 808.06 & $2.6 \times 10^{5}$ & 0.041 \\
\hline
\end{tabular}

\section{DISCUSSION}

The effect of copper ions on corrosion behavior of mild steel and SS 304L in both distilled and artificial seawater was studied at room temperature under both static and dynamic conditions using weight loss and electrochemical techniques. The influence of different environmental variables such as $\mathrm{pH}$, flow velocity, presence of oxidizers, etc on the corrosion rate of metals is 
quite complex and depends upon the characteristics of metal and environment to which it is exposed [13]. For mild steel corrosion there is a complex dependence of corrosion rate on $\mathrm{pH}$. In $\mathrm{pH}$ range 5-9 (near neutral $\mathrm{pH}$ range) the direct role of $\mathrm{pH}$ on the corrosion rate of steel has not been established [14]. In aerated solutions, under static condition, in near neutral $\mathrm{pH}$ range the major reactions controlling corrosion process is the reduction of dissolved $\mathrm{O}_{2}$ and other oxidizers, if any, present into the solution. Further, the corrosion processes that are controlled by activation polarization the dynamic condition (solution agitation) have no effect on the corrosion rate. However, if the corrosion process is under cathodic diffusion control, the dynamic condition increases the corrosion rate.

Considering the present investigation, under static condition at room temperature, the $\mathrm{pH}$ range selected for the study is unlikely to affect the corrosion rate of mild steel. A variation in the corrosion rate of mild steel is expected to be caused by the presence of $\mathrm{Cu}$ ions present into the solution and also the solution composition. Under dynamic conditions, in addition to the above factors, the amount of solution agitation is also likely to influence the corrosion rate. For mild steel immersed in distilled water, the corrosion process under the experimental conditions is controlled by cathodic diffusion and the dynamic condition is expected to cause an increase in corrosion rate. The result of immersion in absence of $\mathrm{Cu}$, show a large increase in corrosion rate of mild steel under dynamic condition. In presence of $\mathrm{Cu}$ ions the corrosion process is reversed and a large decreased in corrosion rate is observed. Under static condition, a lower concentration of $\mathrm{Cu}(<20 \mathrm{ppm})$ causes a slight increase in the corrosion rate. However, as the $\mathrm{Cu}$ concentration is increased in the solution a decreasing trend in the corrosion rate is observed. An increase in the corrosion rate at lower concentration of $\mathrm{Cu}$ is attributed to the additional cathodic reaction involving the reduction of $\mathrm{Cu}$ ions in addition to the reduction of the dissolved oxygen. A decrease in the corrosion rate with increasing $\mathrm{Cu}$ concentration may be due to the deposition of reduced $\mathrm{Cu}$ on the steel surface which forms a protective barrier against further oxidation of steel. In presence of $\mathrm{Cu}^{2+}$ the redox reaction taking place at the steel surface may be written as follows:

$$
\mathrm{Cu}^{2+}+\mathrm{Fe} \rightarrow \mathrm{Cu}+\mathrm{Fe}^{2+}
$$

Consequently, the metallic $\mathrm{Cu}$ formed a protective film on the steel surface. Since the electrode potential of $\mathrm{Cu}\left(\mathrm{Ecu}^{2+} / \mathrm{cu}\right)$ is greater than electrode potential of $\mathrm{Fe}\left(\mathrm{Fe}^{2+} / \mathrm{Fe}\right)$ the film protected the steel efficiently and caused a decrease in corrosion rate. When $\mathrm{Cu}$ concentration reached to a certain value, the above reaction moved forcefully from left to right, and a greater amount of $\mathrm{Cu}$ metal is formed on the steel surface [15]. As a result, the $\mathrm{Cu}$ film thickened quickly and a part of the film is detached from the steel surface. Some particulates of $\mathrm{Cu}$ were observed in the solutions containing higher concentrations of $\mathrm{Cu}$. Further, a good amount of $\mathrm{Cu}$ ions do not participate in the reduction reaction and remained present into the solutions. The estimation of large amount of $\mathrm{Cu}$ ions in the test solutions at the end of the immersion supports the above observation. Under dynamic condition, a large decrease in the corrosion rate in presence of $\mathrm{Cu}$ ions is attributed to the formation of a stable passive film on the steel surface. Under dynamic condition there appears to be a competition between oxygen and $\mathrm{Cu}$ ions and the passive film formed at the substrate is more stable due to the availability of enough oxygen at the 
steel/solution interface. The observed increase in corrosion rate of mild steel in artificial seawater under dynamic condition is due to the absence of passive film on the substrate.

Considering the results of immersion for SS 304L in both distilled and artificial seawater there is no effect of $\mathrm{Cu}$ on the corrosion rate. The results of corrosion rate as estimated by solvent analysis of iron ions is consistent with the results obtained by the weight loss measurements.

The results of immersion tests find support from free corrosion potential measurements. In presence of higher concentration of $\mathrm{Cu}$ there is significant ennoblement in the $E_{\text {corr }}$ of mild steel and SS 304L suggesting the protective role of $\mathrm{Cu}$. Considering the results of potentiodynamic polarization measurements, in general, the corrosion rate of mild steel increases with increasing $\mathrm{Cu}$ concentration. At $\mathrm{pH} 5$, in presence of $1 \mathrm{ppm}$ of $\mathrm{Cu}$ there was a cathodic shift in $E_{\text {corr }}$ making the steel surface more active. However, a lower value of $I_{\text {corr }}$ resulted in the lowering in corrosion rate. At $100 \mathrm{ppm} \mathrm{Cu}$, though there was an anodic shift in $E_{\text {corr }}$ making the steel surface nobler, an increase in the $I_{\text {corr }}$ value caused a substantial increase in the corrosion rate. The corrosion parameters as obtained by the potentiodynamic polarization measurements are instantaneous and increase in the corrosion rate with increasing $\mathrm{Cu}$ concentration can be explained on the basis of additional cathodic reaction involving the reduction of $\mathrm{Cu}$ ions and rapid measurements of rate of electron transfer reactions. For SS 304L, the corrosion parameters as derived from potentiodynamic polarization curves show a positive shift in $E_{\text {corr }}$ values in presence of $\mathrm{Cu}$ ions. As a result the metal surface becomes still nobler.

\section{CONCLUSIONS}

1. The microscopic examination of the mild steel and SS 304L coupons subjected to immersion in distilled and artificial seawater did not show any evidence of localized attack (pitting corrosion) in presence of different concentration of $\mathrm{Cu}$ ions.

2. The results of immersion tests showed a decrease in the corrosion rate of mild steel with increasing $\mathrm{Cu}$ concentration. This is attributed to the deposition of reduced $\mathrm{Cu}$ on the steel surface which protected the steel efficiently and caused a decrease in corrosion rate.

3. SS 304L is unaffected in both distilled and artificial seawater and presence of $\mathrm{Cu}$ in the medium showed no effect on the corrosion rate.

4. The results of immersion tests find support from free corrosion potential measurements. In presence of higher concentration of $\mathrm{Cu}$ there is significant ennoblement in the $E_{\text {corr }}$ of mild steel and SS 304L suggesting the protective role of $\mathrm{Cu}$.

5. The corrosion parameters as derived from potentiodynamic polarization measurements showed an increase in the corrosion rate of mild steel with increasing $\mathrm{Cu}$ concentration. This is explained on the basis of instantaneous measurement of the corrosion parameters and rapid of rate of electron transfer reactions. 


\section{REFERENCES}

[1] Malik, A.U., Kutty, P.C.M., Andijani, I.N. and Al-Fozan, S.A., Materials Performance and Failure Evaluation in SWCC MSF Plants, Desalination, 97, p.171. (1994).

[2] Asphahani, A.I. and Silence, W.L., Metal Hand Book: ASME Publication. 13 p. 113. (1987).

[3] Internal Corrosion of Water Distribution System: Cooperative Research Report, American Water Work Association and DVGW-for Schungsteus, p. 191. (1985)

[4] Schrieber, C.F., Measurement and Control Related Corrosion and Scales in Water Desalination Installation in Measurement of Control in Water Desalination, p. 427. (1986).

[5] L. Kenworthy, The Problems of Copper and Galvanized Iron in Water System, J. Inst. Metals. (1943).

[6] H. Guise, Dissolved copper effect on iron pipe, J.AWWA, 63, p.79. (1971).

[7] G.P. Treweek, R.R. Trusell and R.D. Pomeroy, Copper induced corrosion of galvanized steel pipe, in Proc. 6th Water Technology Conference, Louisville, AWWA, Denver, (1978).

[8] L. Grrasha, W. Rinse and M. Davis, Corrosive Effect of Dissolved Copper on Galvanized Steel, Phase-II, Internal Report, Metropolitan Water District of S.C., (1981).

[9] A.U. Malik and M.A.K. Al-Sofi, Private communication, (1995).

[10] E.A. Al-Sums, S. Aziz, A. Al-Radif, M.S. Said and O. Heikel, Vapor side corrosion of copper base condenser tubes of the MSF desalination plants of Abu Dhabi, Desalination, 97, p.109. (1994).

[11] J. Otaker, Developing Steam purity limits, Power, New York, (1989).

[12] ASTM D1141, Standard Specification for Substitute Ocean Water in Annual Book of ASTM Standards 4.08, ASM International, PA (1996).

[13] M.G. Fontana, Corrosion Engineering, Tata McGraw-Hill Publishing Company Ltd, New Delhi, p. 63. (2006).

[14] Metal Handbook, ASM International, Vol. 13, Corrosion, 9th ed., p. 38. (1987).

[15] T.Gu, Z.Huang, Coll. Surf. 40, p.71. (1989). 